\title{
Extreme Cold Environments: A Suitable Niche for Selection of Novel Psychrotrophic Microbes for Biotechnological Applications
}

\author{
Ajar Nath Yadav ${ }^{*}$, Priyanka Verma ${ }^{2}$, Vinod Kumar ${ }^{1}$, Shashwati Ghosh Sachan ${ }^{3}$ and Anil Kumar Saxena ${ }^{4}$ \\ ${ }^{1}$ Department of Biotechnology, Eternal University, India \\ ${ }^{2}$ Department of Microbiology, Eternal University, India \\ ${ }^{3}$ Department of Bio-Engineering, Birla Institute of Technology, India \\ ${ }^{4}$ ICAR-National Bureau of Agriculturally Important Microorganisms, India
}

Submission: January 27, 2017; Published: February 06, 2017

*Corresponding author: Ajar Nath Yadav, Assistant professor, Department of Biotechnology, Akal College of Agriculture, Eternal University, India, Tel: +91-9882545085; Email: ajarbiotech@gmail.com

\section{Editorial}

The microbiomes of cold environments are of particular importance in global ecology since the majority of terrestrial and aquatic ecosystems of our planet are permanently or seasonally submitted to cold temperatures. Earth is primarily a cold, marine planet with $90 \%$ of the ocean's waters being at $5{ }^{\circ} \mathrm{C}$ or lower. Permafrost soils, glaciers, polar sea ice, and snow cover make up $20 \%$ of the Earth's surface environments. Microbial communities under cold habitats have been undergone the physiological adaptations to low temperature and chemical stress. Recently, these communities have attained the focus of applied research not only in terms of biotechnological prospects but also to understand the use of primitive analogues of biomolecules existed during early Earth environments [1,2]. The microbiomes of cold environments have been extensively investigated in the past few years with a focus on culture dependent and culture-independent techniques. Cold-adapted microorganisms have been reported from Antarctic sub-glacial, permanently ice-covered lakes, cloud droplets, ice cap cores from considerable depth, snow and ice glaciers [3-6]. Many novel microbes have been sort out from cold environments including Halobacterium lacusprofundi [7], Sphingobacterium antarcticus [8], Octadecabacter arcticus [9], Hymenobacter roseosalivarius [10], Cellulophaga algicola [11], Flavobacterium frigidarium [12], Oleispira antarctica [13], Flavobacterium psychrolimnae [14], Psychromonas ingrahamii [15], Exiguobacterium soli [16], Pseudomonas extremaustralis [17], Cryobacterium roopkundense [18], Sphingomonas glacialis [19], Pedobacter arcticus [20], Sphingobacterium psychroaquaticum [21], Lacinutrix jangbogonensis [22], Massilia eurypsychrophila [23], Glaciimonas frigoris [24] and Psychrobacter pocilloporae [25]. There are several reports on whole genome sequences of novel and potential psychrotrophic microbes [26,27].

The novel species of psychrotrophic microbes have been isolated worldwide and reported from different domain archaea, bacteria and fungi which included members of phylum Actinobacteria, Proteobacteria, Bacteroidetes, Basidiomycota, Firmicutes and Euryarchaeota [7-25]. Along with novel species of psychrotrophic microbes, some microbial species including Arthrobacter nicotianae, Brevundimonas terrae, Paenibacillus tylopili and Pseudomonas cedrina have been reported first time from cold deserts of NW Himalayas and exhibited multifunctional plant growth promoting (PGP) attributes at low temperatures [5]. In a study by Yadav et al. [6], the microbial species Alishewanella sp., Aurantimonas altamirensis, Bacillus baekryungensis, $B$. marisflavi, Desemzia incerta, Paenibacillus xylanexedens, Pontibacillus sp., Providencia sp., P. frederiksbergensis, Sinobaca beijingensis and Vibrio metschnikovii have been reported first time from high altitude and low temperature environments of Indian Himalayas. Wheat associated psychrotrophic bacteria Arthrobacter methylotrophus and Pseudomonas rhodesiae have been reported first time from wheat growing in North hills zone of India [28]. In a specific search of economically important Bacillus and Bacillus derived genera (BBDG) at low temperature, Various BBDG such as Bacillus psychrosaccharolyticus, $B$. amyloliquefaciens, B. altitudinis, B. Muralis, Paenibacillus tylopili, P. pabuli, P. terrae and P. lautus with efficient PGP attributes have been reported first time by Yadav et al. [29].

Prospecting the cold habitats has led to the isolation of a great diversity of psychrotrophic microbiomes. The bacterial 
diversity from the cold environment could serve as a database for selection of bio-inoculants with PGP ability and could be used for improving the growth and yield of crops grown at high altitudes with prevailing low temperatures [30-33]. Psychrotrophic PGP microbes have been shown to promote plant growth either directly by biological $\mathrm{N}_{2}$-fixation; solubilization of minerals such as phosphorus, potassium and zinc; production of siderophores and plant growth hormones (Indole acetic acid and gibberellic acid) or indirectly, via production of antagonistic substances by inducing resistance against plant pathogens [29,34,35]. The psychrotrophic PGP microbes can have an impact on plant growth providing the plant with compound(s) of microbial origin for facilitating the uptake of nutrients from the environment. Psychrotrophic PGP microbes were found in several genera, including Arthrobacter, Bacillus, Brevundimonas Burkholderia, Pseudomonas, Citricoccus, Exiguobacterium, Flavobacterium, Janthinobacterium, Kocuria, Lysinibacillus, Methylobacterium, Microbacterium, Paenibacillus, Providencia and Serratia [3538]. Among these taxa, Pseudomonas and Exiguobacterium has been the best characterized for PGP at low temperatures [38,39]. There are several studies have demonstrated the benefits of PGP microbes on the growth and yield of different crops at different climates, soils, and temperatures. The use of PGP microbes improves plant growth by supplying plant nutrients, which can help sustain environmental health and soil productivity.

Psychrophilic/psychrotolerant microbes are important for many reasons, particularly because they produce coldactive enzymes. The enzymes from psychrophiles have become interesting for industrial applications, partly because of ongoing efforts to decrease energy consumption. These cold-active enzymes provide opportunities to study the adaptation of life to low temperature and the potential for biotechnological exploitation $[2,40]$. Most of the work that has been conducted on psychrophilic bacteria focused on cold-active enzymes such as amylase, protease, lipase, pectinase, xylanase, cellulase, $\beta$-glucosidase, $\beta$-galactosidase and chitinase [40]. Coldactive enzymes are produced by psychrophilic microbes namely, Acinetobacter, Aquaspirillium, Arthrobacter, Bacillus, Carnobacterium, Clostridium, Cytophaga, Flavobacterium, Marinomonas, Moraxella, Moritella, Paenibacillus, Planococcus, Pseudoalteromonas, Pseudomonas, Psychrobacter, Shewanella, Vibrio and Xanthomonas [27,41,42]. Psychrophilic microbes can be applied for biodegradation of agro wastes at low temperatures. Shukla et al. [43], have developed psychrotrophic microbial consortium of Eupenicillium crustaceum, Paceliomyces sp., Bacillus atropheus and Bacillus sp., for its potential applications towards degradation of agri-residues and conversion to a value added product like compost for enhancing soil fertility and decreasing environmental pollution caused by burning of agro-wastes. Psychrotrophic microbes produced anti-freezing compounds (AFCs) at low temperatures [1,27]. The AFCs are useful in cryosurgery and also in the cryopreservation of isolated organs, cell lines, tissues and whole organisms. In food industry, anti-freezing proteins (AFPs) can be used to improve the quality of frozen food. Improved cold tolerance in fishes has been achieved in some cases by direct injection of AFPs and in another case by transgenic expression of an AFPs.

\section{Conclusion}

Cold-adapted microbes could be utilized for understanding adaptation at low temperatures, as they produce cold-active enzymes, fatty acids, carotenoids, cold acclimation proteins, cryoprotectants and anti-freezing proteins under extreme conditions of low temperature. Cold-active enzymes have applications in industry like those manufacturing cleaning agents or in leather processing. The other applications could be for bio-degradation of xenobiotic compounds in cold climes, food processing (bakery, cheese manufacture and fermentation) and molecular biology (heterologous gene expression). Coldadapted microbes have attracted the attention of the scientific community due to their ability to promote plant growth and produce cold-active enzymes, with potential biotechnological applications in a broad range of industrial, agricultural and medical processes. Psychrotrophic microbes could be valuable in agriculture as bio-inoculants and biocontrol agents for low temperature habitats. The use of psychrophiles as biofertilizers, biocontrol agent and bioremediators would be of great use in agriculture under cold climatic conditions.

\section{References}

1. Yadav AN (2015) Bacterial diversity of cold deserts and mining of genes for low temperature tolerance. Ph.D Thesis- IARI, New Delhi,India, pp. 234.

2. Saxena AK, Yadav AN, Rajawat MVS, Kaushik R, Kumar R, et al. (2016) Microbial Diversity of Extreme Regions: An Unseen Heritage and Wealth. Indian J Plant Genet Resour 29(3): 246-248.

3. Yadav AN, Verma P, Kumar M, Pal KK, Dey R, et al. (2015) Diversity and phylogenetic profiling of niche-specific Bacilli from extreme environments of India. Ann Microbiol 65(2): 611-629.

4. Srivastava AK, Kumar S, Kaushik R, Saxena AK, Padaria JC, et al. (2013) Diversity analysis of Bacillus and other predominant genera in extreme environments and its utilization in agriculture, Technical Report.

5. Yadav AN, Sachan SG, Verma P, Saxena AK (2015) Prospecting cold deserts of north western Himalayas for microbial diversity and plant growth promoting attributes. J Biosci Bioeng 119(6): 683-693.

6. Yadav AN, Sachan SG, Verma P, Tyagi SP, Kaushik R, et al. (2015) Culturable diversity and functional annotation of psychrotrophic bacteria from cold desert of Leh Ladakh (India). World J Microbiol Biotechnol 31(1): 95-108.

7. Franzmann P, Stackebrandt E, Sanderson K, Volkman J, Cameron D, et al. (1988) Halobacterium lacusprofundi sp. nov., a halophilic bacterium isolated from Deep Lake, Antarctica. Syst App Microbiol 11(1): 20-27.

8. Shivaji S, Ray M, Rao NS, Saisree L, Jagannadham M, et al. (1992) Sphingobacterium antarcticus sp. nov., a psychrotrophic bacterium from the soils of Schirmacher Oasis, Antarctica. Int J Syst Evol Microbiol 42(1): 102-106.

9. Gosink J, Herwig R, Staley J (1997) Octadecabacter arcticus gen. nov., sp. nov., and $O$. antarcticus, sp. nov., nonpigmented, psychrophilic gas vacuolate bacteria from polar sea ice and water. Syst Appl Microbiol 20(3): 356-365. 
10. Hirsch P, Ludwig W, Hethke C, Sittig M, Hoffmann B, et al. (1998) Hymenobacter roseosalivarius gen. nov., sp. nov. from continental Antarctic soils and sandstone: bacteria of the Cytophaga/ Flavobacterium/Bacteroides line of phylogenetic descent. Syst Appl Microbiol 21(3): 374-383.

11. Bowman JP (2000) Description of Cellulophaga algicola sp. nov. isolated from the surfaces of Antarctic algae, and reclassification of Cytophaga uliginosa (ZoBell and Upham 1944) Reichenbach 1989 as Cellulophaga uliginosa comb. nov. Int J Syst Evol Microbiol 50(5): 1861-1868.

12. Humphry DR, George A, Black GW, Cummings SP (2001) Flavobacterium frigidarium sp. nov., an aerobic, psychrophilic, xylanolytic and laminarinolytic bacterium from Antarctica. Int J Syst Evol Microbiol 51(4): 1235-1243.

13. Yakimov MM, Giuliano L, Gentile G, Crisafi E, Chernikova TN, et al. (2003) Oleispira antarctica gen. nov., sp. nov., a novel hydrocarbonoclastic marine bacterium isolated from Antarctic coastal sea water. Int J Syst Evol Microbiol 53(3): 779-785.

14. Van Trappen S, Vandecandelaere I, Mergaert J, Swings J (2005) Flavobacterium fryxellicola sp. nov. and Flavobacterium psychrolimnae sp. nov., novel psychrophilic bacteria isolated from microbial mats in Antarctic lakes. Int J Syst Evol Microbiol 55(2): 769-772.

15. Auman AJ, Breezee JL, Gosink JJ, Kämpfer P, Staley JT (2006) Psychromonas ingrahamii sp. nov., a novel gas vacuolate, psychrophilic bacterium isolated from Arctic polar sea ice. Int J Syst Evol Microbiol 56(5): 1001-1007.

16. Chaturvedi P, Prabahar V, Manorama R, Pindi PK, Bhadra B, et al (2008) Exiguobacterium soli sp. nov., a psychrophilic bacterium from the McMurdo Dry Valleys, Antarctica. Int J Syst Evol Microbiol 58(10): 2447-2453

17. López NI, Pettinari MJ, StackebrandtE, Tribelli PM, Põtter M, etal. (2009) Pseudomonas extremaustralis sp. nov., a poly (3-hydroxybutyrate) producer isolated from an Antarctic environment. Curr Microbio 59(5): 514-519.

18. Reddy G, Pradhan S, Manorama R, Shivaji S (2010) Cryobacterium roopkundense sp. nov., a psychrophilic bacterium isolated from glacial soil. Int J Syst Evol Microbiol 60(4): 866-870.

19. Zhang DC, Busse HJ, Liu HC, Zhou YG, Schinner F, et al. (2011) Sphingomonas glacialis sp. nov., a psychrophilic bacterium isolated from alpine glacier cryoconite. Int J Syst Evol Microbiol 61(3): 587-591.

20. Zhou Z, Jiang F, Wang S, Peng F, Dai J, et al. (2012) Pedobacter arcticus sp. nov., a facultative psychrophile isolated from Arctic soil. Int J Syst Evol Microbiol 62(8): 1963-1969.

21. Albert RA, Waas NE, Pavlons SC, Pearson JL, Ketelboeter L, et al. (2013) Sphingobacterium psychroaquaticum sp. nov., a psychrophilic bacterium isolated from Lake Michigan water. Int J Syst Evol Microbiol 63(3): 952-958.

22. Lee YM, Hwang CY, Lee I, Jung YJ, Cho Y, et al. (2014) Lacinutrix jangbogonensis sp. nov., a psychrophilic bacterium isolated from Antarctic marine sediment and emended description of the genus Lacinutrix. Antonie Van Leeuwenhoek 106(3): 527-533.

23. Shen L, Liu Y, Gu Z, Xu B, Wang N, et al. (2015) Massilia eurypsychrophila sp. nov. a facultatively psychrophilic bacteria isolated from ice core. Int J Syst Evol Microbiol 65(7): 2124-2129.

24. Margesin R, Zhang DC, Frasson D, Brouchkov A (2016) Glaciimonas frigoris sp. nov., a psychrophilic bacterium isolated from ancient Siberian permafrost sediment, and emended description of the genus Glaciimonas. Int J Syst Evol Microbiol 66(2): 744-748.

25. Zachariah S, Kumari P, Das SK (2016) Psychrobacter pocilloporae sp. nov., isolated from a coral, Pocillopora eydouxi. Int J Syst Evol Microbiol 66(12): 5091-5098.
26. Kim SJ, Shin SC, Hong SG, Lee YM, Choi IG, et al. (2012) Genome sequence of a novel member of the genus Psychrobacter isolated from Antarctic soil. J Bacteriol 194(9): 2403.

27. Singh RN, Gaba S, Yadav AN, Gaur P, Gulati S, et al. (2016) First, High quality draft genome sequence of a plant growth promoting and Cold Active Enzymes producing psychrotrophic Arthrobacter agilis strain L77. Stand Genomic Sci 11(1): 54

28. Verma P, Yadav AN, Khannam KS, Panjiar N, Kumar S, et al. (2015) Assessment of genetic diversity and plant growth promoting attributes of psychrotolerant bacteria allied with wheat (Triticum aestivum) from the northern hills zone of India. Ann Microbiol 65(4): 1885-1899.

29. Yadav AN, Sachan SG, Verma P, Saxena AK (2016) Bioprospecting of plant growth promoting psychrotrophic Bacilli from cold desert of north western Indian Himalayas. Indian J Exp Biol 52(2): 142-150.

30. Kumar V, Yadav AN, Saxena A, Sangwan P, Dhaliwal HS (2016) Unravelling Rhizospheric Diversity and Potential of Phytase Producing Microbes. SM J Biol 2(1): 1009

31. Yadav AN, Sachan S, Kaushik R, Saxena AK (2014) Cold tolerant microbes from Indian Himalayas: diversity and potential applications in biotechnology and agriculture. In: Proceeding of $84^{\text {th }}$ Annual Session of NASI and Symposium on "Desert Science-Opportunities and challenges", pp. 17.

32. Kumar V, Singh P, Jorquera MA, Sangwan P, Kumar P, et al. (2013) Isolation of phytase-producing bacteria from Himalayan soils and their effect on growth and phosphorus uptake of Indian mustard (Brassica juncea). World J Microbiol Biotechnol 29(8): 1361-1369.

33. Yadav AN, Verma P, Sachan S, Kaushik R, Saxena AK (2016) Microbiome of Indian Himalayan regions: Molecular diversity, phylogenetic profiling and biotechnological applications. In: Proceeding of $86^{\text {th }}$ Annual Session of NASI \& Symposium on "Science, Technology and Entrepreneurship for Human Welfare in The Himalayan Region" pp. 58.

34. Verma P, Yadav AN, Shukla L, Saxena AK, Suman A (2015) Alleviation of cold stress in wheat seedlings by Bacillus amyloliquefaciens IARIHHS2-30, an endophytic psychrotolerant K-solubilizing bacterium from NW Indian Himalayas. Natl J Life Sci 12(2): 105-110.

35. Verma P, Yadav AN, Khannam KS, Kumar S, Saxena AK, et al. (2016) Molecular diversity and multifarious plant growth promoting attributes of Bacilli associated with wheat (Triticum aestivum L.) rhizosphere from six diverse agro-ecological zones of India. J Basic Microbiol 56(1): 44-58.

36. Saxena AK, Yadav AN, Kaushik R, Tyagi SP, Shukla L (2015) Biotechnological applications of microbes isolated from cold environments in agriculture and allied sectors. In: Proceedings International Conference on "Low Temperature Science and Biotechnological Advances" Society of low temperature biology, pp. 104.

37. Verma P, Yadav AN, Khannam KS, Kumar S, Saxena AK, et al. (2015) Plant growth promotion and mitigation of cold stress in inoculated wheat (Triticum aestivum L.) by K-solubilizing psychrotolerant Methylobacterium phyllosphaerae strain IARI-HHS2-67. In: Proceeding of International conference on "Low Temperature Science and Biotechnological Advances" Society of Low Temperature Biology, pp. 175 .

38. Yadav AN, Verma P, Sachan S, Kaushik R, Saxena AK (2013) Diversity and phylogeny of low temperature plant growth promoting fluorescent Pseudomonas isolated from cold desert of north western Himalayas. In: Proceeding of $54^{\text {th }} \mathrm{AMI}$ and International symposium on "Frontier Discoveries and Innovations in Microbiology and its Interdisciplinary Relevance" pp. 397-397.

39. Yadav AN, Verma P, Sachan S, Kaushik R, Saxena AK (2015) Mitigation of cold stress for growth and yield of wheat (Triticum aestivum L.) by 
psychrotrophic pseudomonads from cold deserts of Indian Himalayas. In: Proceeding of $56^{\text {th }}$ AMI and International symposium on "Emerging Discoveries in Microbiology".

40. Yadav AN, Sachan SG, Verma P, Kaushik R, Saxena AK (2016) Cold active hydrolytic enzymes production by psychrotrophic Bacilli isolated from three sub-glacial lakes of NW Indian Himalayas. J Basic Microbiol 56(3): 294-307.

41. Gerday C, Aittaleb M, Bentahir M, Chessa JP, Claverie P, et al. (2000) Cold-adapted enzymes: from fundamentals to biotechnology. Trend Biotechnol 18(3): 103-107.
42. Groudieva T, Kambourova M, Yusef H, Royter M, Grote R, et al. (2004) Diversity and cold-active hydrolytic enzymes of culturable bacteria associated with Arctic sea ice, Spitzbergen. Extremophiles 8(6): 475488.

43. Shukla L, Suman A, Yadav AN, Verma P, Saxena AK (2016) Syntrophic microbial system for ex-situ degradation of paddy straw at low temperature under controlled and natural environment. J Appl Biol Biotechnol 4(2): 30-37.

\section{Your next submission with Juniper Publishers will reach you the below assets}

- Quality Editorial service

- Swift Peer Review

- Reprints availability

- E-prints Service

- Manuscript Podcast for convenient understanding

- Global attainment for your research

- Manuscript accessibility in different formats

( Pdf, E-pub, Full Text, Audio)

- Unceasing customer service

Track the below URL for one-step submission https://juniperpublishers.com/online-submission.php 